\title{
CRIMINAL AND CRIMINOLOGICAL FACTORS AFFECTING INVOLVEMENT OF MINORS IN ILLEGAL ACTIVITIES AND INDUCEMENT TO USE NARCOTICS, PSYCHOTROPIC SUBSTANCES OR THEIR ANALOGUES
}

\author{
Ganna Sobko ${ }^{1}$ \\ ${ }^{I}$ Ph.D., Associate Professor, Professor of Criminal Law, Criminology and Penalty law Department, Odesa \\ State University of Internal Affairs, Odesa, Ukraine, e-mail: sobkoganna1984@ukr.net, ORCID: \\ https://orcid.org/0000-0002-5938-3400
}

\begin{abstract}
In the case of mental violence, the child is defenseless and unable to protect himself from verbal (constant, systematic, or periodic) insults, threats, humiliation, indifference to him, as well as requirements that do not meet his age and are to her by adult members of her family. More and more often it is possible to hear "My child, I do what I want", which determines the relevance of the chosen topic. The aim of the article is to identify criminal and criminological factors affecting the employment of minors in illegal activities and incitement to use drugs, psychotropic substances or their analogues. The research methodology: the methods of statistics and logical comparison, systematization, and generalization, which made it possible to achieve the goal of the study. The factors that influence the formation of the child's psyche are analyzed. Also based on the studied criminal cases, namely statistics under article 304 " involvement of juveniles in illegal activity" and 315 "addiction to use of drugs, medicines. The changes which according to the author will affect the improvement of a situation are offered.
\end{abstract}

Keywords: involvement in criminal activity, mental influence on the minor, juvenile delinquency, mental violence, domestic violence

JEL Classification: I30, K24, K33, K14

Formulas: 0; fig.: 4; tabl.: 0; bibl.: 9

Introduction. Mental abuse of children is a form of systematic (constant) abuse or neglect of a child committed by his parents or close relatives (guardians, trustees, adoptive parents, or persons raising a child). Such violence can cause serious damage to the emotional, social, and psychological development of the child [1, 12-15].

A feature of domestic non-physical violence against children is the systematic nature, the purpose of which is to gain full power and control over the child. According to many psychologists, in the first five years of a person's life, a personality structure is formed that develops throughout life. In this period of knowledge of the world, the child is most vulnerable, both physically and mentally, because, completely dependent on their loved ones - what is the standard of relations for her $[2,100]$.

That is why when adults (parents) commit violence against children, they (children) are defenseless and mentally (physically) underdeveloped to repel their abuser.

Today, such types of mental violence against children as ignoring, manipulating, isolating, insulting, humiliating, denying needs, terrorizing, or neglecting a child are defined. 
It is important to note that parents are usually aware that they are committing violence, such as humiliation, blackmail of the child. However, there are cases when parents unknowingly subject a child to mental violence.

Disgust, demonstration of dislike, hostility to the child, negative evaluation, focusing exclusively on the negative traits and characteristics of the child, frustration of the basic needs of the child, including long-term deprivation of minors love, tenderness, care, and security from parents, coercion to loneliness can also be attributed to the emotional impact and mental violence.

Parental neglect is one of the most harmful forms of domestic violence. Prerequisites for parents' indifference to their children's needs can be the personal qualities of parents, the presence of past violence, stress related to the identity of parents and financial problems, job loss, health, family relationships, etc $[3,15]$.

The consequences of mental violence in childhood depend on its duration and intensity. They manifest themselves in the form of the child's recognition of his helplessness and insignificance, it is a feeling of guilt, shame, and as a consequence, low self-esteem, self-doubt.

A minor with low self-esteem constantly feels guilt, shame, anxiety attacks, which with age can lead to severe depression, which is accompanied by sleep disturbances, feelings of helplessness, inferiority. Adolescents who suffer from loneliness may attempt suicide. As they grow older, victims of domestic violence may become depressed without realizing their condition. The consequences of such violence can be not only aggression but also excessive passivity, lack of ability to self-defense, victimhood. Such teenagers are most often emotionally depressed and seek to attract attention in any way, including rude and eccentric behavior.

In conclusion, it should be noted that if adolescents are brought up in an atmosphere of psychological pressure and violence, the latter leaves an imprint for life, and leads to various consequences, in the form of mental disorders, which further create the preconditions for the victim and prolonged depression, which will further lead to suicide) or the subject of a criminal offense [4, 115-118].

Aims. The purpose of the article is to identify criminal and criminological factors affecting the employment of minors in illegal activities and incitement to use drugs, psychotropic substances or their analogues

Methods. The author used the methods of statistics and logical comparison, systematization, and generalization, which made it possible to achieve the goal of the study.

Results. The author notes that it is necessary to distinguish between the consequences of mental violence, such as:

1) approximate consequences, ie such reactions as arousal, desire to run away, hide, take action (including criminal) to attract the attention of parents to themselves (minors), or vice versa manifest themselves in the form of deep inhibition, external indifference, but in both cases, minors are driven by fear, anxiety, anger, etc .; 
2) long-term consequences, which manifest themselves in the form of diseases, personal and emotional disorders of physical and mental development, including severe social consequences. Severe social consequences include not only the commission of criminal offenses, such as murder or suicide by minors but also the formation of antisocial, maladapted individuals with increased aggression (including unmotivated), violence against younger animals, etc.

In the context of the research topic, the consequences of juvenile violence and criminal offenses need to be thoroughly analyzed. Juveniles who have experienced violence develop personal changes in behavior that are unattractive to others, resulting in difficulties in their socialization. If a juvenile does not have a sufficient level of knowledge and erudition to gain credibility in a school (school), he or she can join the criminal sphere, become accustomed to alcohol and drugs, and again commit criminal offenses.

It is believed that violence against children can lead to difficulties in starting a family, giving birth to children, because they will not be able to give their children enough warmth, love, etc. In the context of the research on this issue, a survey of 1,570 people (juveniles of secondary schools, underage students, and cadets of higher education institutions) was conducted, of which the question "How do you see your future family?" only $2.7 \%$ of respondents said they would never start a family, or their children were not as unhappy, others expressed a desire to start a happy family [9].

It should be noted that in recent years at the legislative level there has been an active fight against domestic violence, including mental, however, at the stage of implementation of the Law of Ukraine "On Prevention and Counteraction to Domestic Violence" № 2229-VIII from 07.12.2017 the following issues were identified, as:

- underdevelopment of juvenile justice, which is the lack of sufficient legal mechanisms aimed at ensuring the rights and freedoms and interests of minors, including those aimed at preventing and combating juvenile delinquency;

- Lack of a sufficient number of family-type homes, centers that could protect adolescents who are subjected to domestic violence, including lack of state funding for socialization programs for minors who have been victims of domestic violence;

- Lack of modern legal mechanisms for detecting and preventing mental violence against minors. For example, the survey found that $25.85 \%$ of respondents would be ashamed to seek help from law enforcement agencies in connection with the perpetration of mental violence against them. At the same time, when asked who the respondents could tell about the commission of such violence against them: $27.05 \%$ stated that they would not tell anyone about the commission of violence against them; $27.5 \%$ of adolescents reported that parents; $15.1 \%$ - to friends; $5.2 \%-$ to an anonymous specialist; $2.5 \%$ - to a social specialist, $2.45 \%$ - to relatives; $1.4 \%$ to foreign acquaintances; $1.25 \%$ - to the police. Given the prevalence of the Internet and social networks, taking into account the above indicators of adolescent isolation, 
it is necessary to introduce in social networks anonymous groups to help minors who have suffered from mental violence. The purpose of such groups will be to identify cases and preconditions for mental violence and provide assistance to victims. Based on the received data the state measures of counteraction to mental violence (generalsocial, special-criminological, and individual-educational) concerning minors will be further developed that will allow counteracting violence more effectively [9].

- the issue of employment of minors has not been regulated, with the help of which it was possible to help reduce the crime rate among adolescents and to counteract the provocation of domestic violence against adolescents, etc.

As a result, due to insufficient state regulation and lack of legal mechanisms for the socialization of children victims of mental violence, such problematic issues become factors that increase the crime rate among minors, such as involving minors in prostitution (Part 3 of Art. 303 of the Criminal Code of Ukraine), the involvement of minors in criminal activity (Article 304 of the Criminal Code of Ukraine), the inclination of minors to use narcotic drugs, psychotropic substances or their analogs (Part 2 of Article 315 of the Criminal Code of Ukraine), the inclination of minors to use intoxicants are narcotic or psychotropic drugs or their analogs (Article 324 of the Criminal Code of Ukraine), etc.

In the absence of a proper upbringing, the presence of mental influence from parents, adolescents have a desire to highlight their independence and somehow realize themselves, including justifying the trust of adults, which motivate minors to commit criminal offenses and create a basis for unimpeded involvement in crime [5, 231].

The involvement of minors in criminal offenses can be carried out with the help of both physical and mental influence. In this regard, special attention needs to be paid to the analysis of criminal offenses under Art. 303, 304, 315, 324 of the Criminal Code of Ukraine, as these criminal offenses have a high degree of public danger, affecting the normal development and health of minors, as well as causing harmful consequences.

Analyzing the disposition of Part 3 of Article 303 of the Criminal Code of Ukraine, it is seen that coercion or involvement in prostitution of a minor is the actions of the subject of a criminal offense aimed at coercing a minor against his desire to engage in prostitution. In this context, we consider coercion as a mental influence, which consists in:

1) the threat of violence (such a threat must concern the victim himself and be perceived as real);

2) the threat of destruction of property (the peculiarity is that in this case, the property must belong to the minor);

3) blackmail (which consists of the threat of exposing information that compromises the person, or consists in the threat of causing harm by intimidation, disclosure of certain information that the teenager wants to hide or not disclose, etc.). In this case, the criminal offense is considered completed from the moment of 
committing the above actions, ie not depending on whether sexual services were provided to minors.

The subject of the criminal offense forces the juvenile to engage in prostitution through mental influence, namely threats that the victim (juvenile) perceives as real.

According to the disposition of Article 304 of the Criminal Code of Ukraine, the object of a criminal offense is public relations and moral principles of the society in the field of education of minors, as well as the protection of the latter from negative illegal influence. The objective side of the criminal offense is the involvement of minors:

1) in criminal activity;

2) intoxication (ie arousal in adolescents of the desire to regularly drink alcohol);

3 ) in begging (ie, the intentional inclination of a minor to systematic (three or more times) begging for money and other material values);

4) in gambling (intentional inclination of a teenager to systematic (three or more times) gambling, etc.).

The subjective side of a criminal offense is characterized by direct intent.

In this case, involvement should be understood as the commission of certain actions by the subject of a criminal offense (a convicted person who has reached 18 years of age) to induce a minor's desire (determination, desire) to perform the actions provided by the article. Involvement is carried out by physical or mental influence on the consciousness of the minor, as a result of which the latter performs the desired action for the subject of his own volition.

It is due to the unstable psyche of minors that they are easily exposed to mental influence, which is used by the subjects of criminal offenses, through persuasion (convictions, requests), promises, intimidation, deception, threats, bribery, envy, incitement to revenge or other motives. are committed without the use of physical force.

Discussion. Moreover, special attention needs to be paid to the distinction between "involvement" and "use" of a minor in criminal activities. Because, "involvement" should be understood as the decision of a minor to participate in criminal activity, which arises as a result of influencing him in one or more ways of mental influence. Under "use" should be understood as non-awareness of minors of their actions, that is the use of adolescents is an "instrument" of a criminal offense (for example, young children who open their wallets).

The criminal offense is provided by Art. 304 of the Criminal Code of Ukraine, is considered completed from the moment of carrying out any physical or mental influence on the minor, irrespective of whether the last committed a criminal offense.

During the study of this topic, the level of criminal prosecution under Art. 304 of the Criminal Code of Ukraine from 2013 to 2019. For 6 years in Ukraine 933 convictions under Art. 304 of the Criminal Code of Ukraine "Involvement of minors in criminal activity". Since 2013, the number of convictions under Art. 304 of the 
Criminal Code of Ukraine began to decrease, namely in 2014180 cases were passed, in 2015 - 159 cases were passed, in 201699 cases were passed, in 2017 - 87 convictions, in $2018-79$ cases, and $2019-63$ convictions.

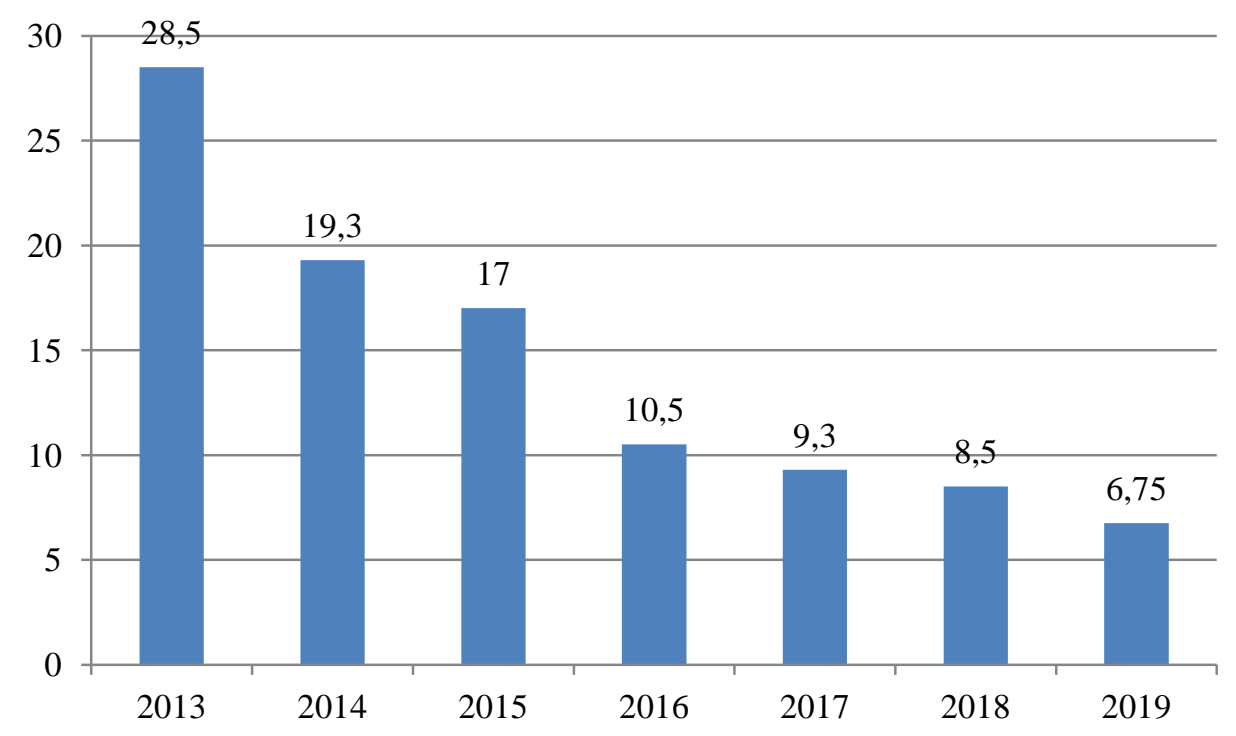

Fig. 1. Dynamics of convictions over 6 years under art. 304 of the Criminal Code of Ukraine "Involvement of minors in illegal activities", \%

On a territorial basis, the largest number of cases was passed in Dnipropetrovsk region (87 cases), Zakarpattia (73 cases), Zaporizhia (70 cases), Luhansk (64 cases), Odesa and Kharkiv (52 cases each), Mykolaiv, Zhytomyr, Donetsk (49 cases each). areas.

The number of registered criminal offenses under Art. 304 of the Criminal Code of Ukraine, for 2017 - 2083 criminal offenses (of which 2000 - involvement in criminal activities, 32 - involvement in drunkenness, 51 - involvement in begging), of which sent to court only 690 criminal proceedings against persons who previously committed criminal offenses, 81 committed by a group of persons, 126 committed in a state of intoxication, 64 by minors or with their participation, 166 criminal proceedings were closed, and in 254 criminal proceedings no decision was made at the end of the reporting year [6].

In 2018, 1,824 criminal offenses were registered (of which 1,739 were involved in criminal activities, 21 were involved in drunkenness, 57 were involved in begging), of which 388 criminal proceedings were committed against persons who had previously committed criminal offenses, 84 committed by a group of persons, 77 committed in a state of intoxication, 81 by minors or with their participation. At the same time, 166 criminal proceedings were closed, and in 204 criminal proceedings, no decision was made at the end of the reporting period.

During 2019, 1,064 criminal proceedings with signs of criminal offenses were registered (of which 956 - involvement in criminal activity, 34 - involvement in drunkenness, 67 - involvement in begging), sent to court a total of 333 criminal 
proceedings committed by persons who had previously committed criminal offenses 80 committed by a group of persons, 87 committed in a state of intoxication, 56 by minors or with their participation. At the same time, 82 criminal proceedings were closed, and in 114 criminal proceedings, no decision was made at the end of the reporting period. The above statistics indicate that in Ukraine there is a dynamics of reducing the commission of criminal offenses of involvement in the criminal activities of minors [7].

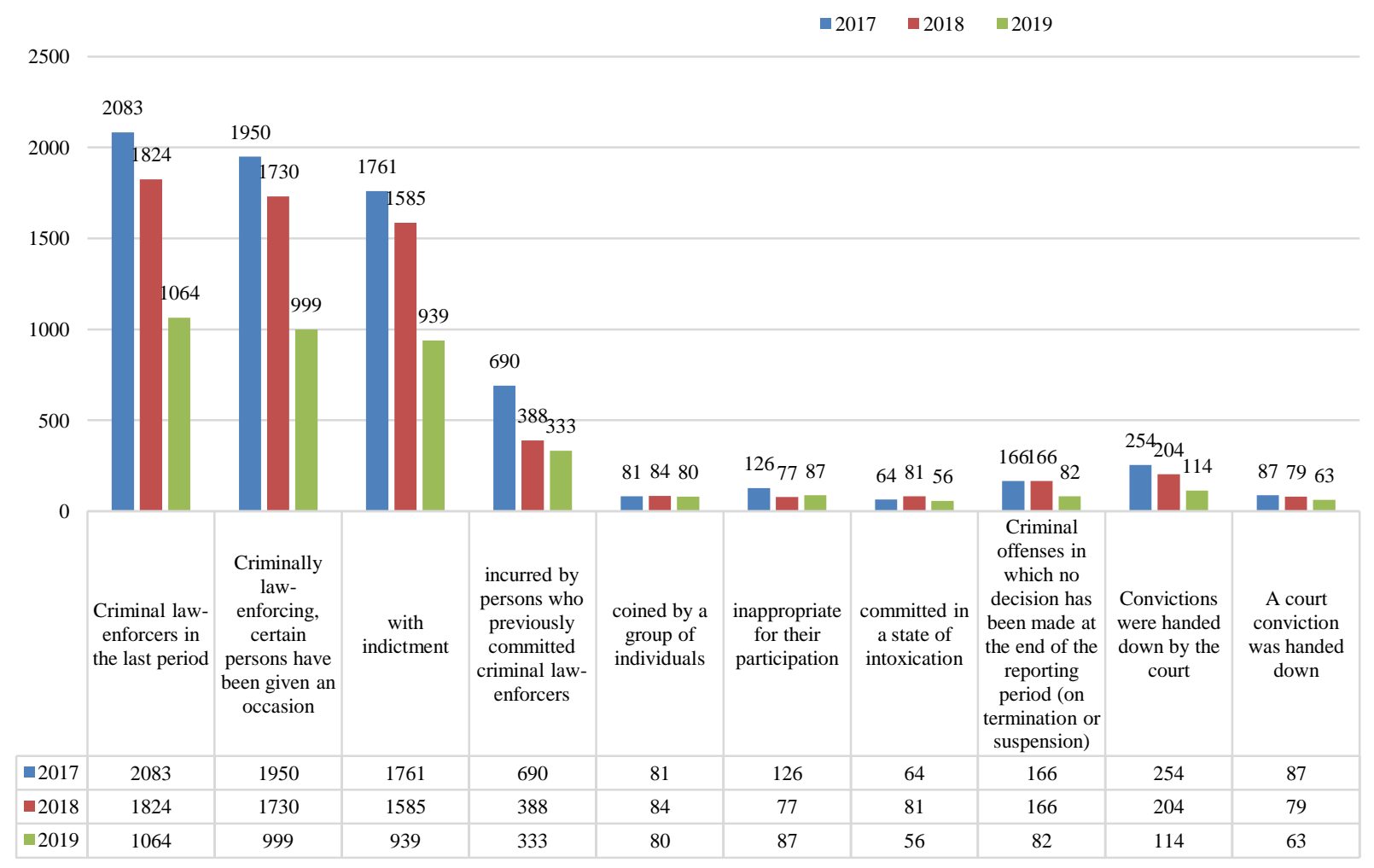

Fig. 2. Dynamics of reducing the commission of criminal offenses of involvement in the criminal activities of minors

The next criminal offense in the context of mental influence on minors is the predisposition of minors to use drugs, psychotropic substances, or their analogs and precursors, provided for in Part 2 of Art. 315 of the Criminal Code of Ukraine.

The object of the criminal offense is the health of the population, namely minors. The objective side is characterized by the non-violent inclination of a minor to use narcotic drugs, psychotropic substances, or their analogs, including disposable ones. It is the "predisposition" that characterizes the actions of the subject of the criminal offense, as a result of which the adult has (manifests) a desire to use drugs or obtain consent from a teenager for such use. Consent can be given as a result of such types of psychological influence (inclination) as persuasion, advice, suggestions, beliefs, threats, blackmail, etc. 
The criminal offense is considered completed from the moment of committing actions of the subject of the criminal offense aimed at attracting persons for consumption, in this case, the degree of intoxication of the juvenile does not matter, as well as the fact whether the victim has previously used such substances.

The subject of a criminal offense is a sane person who has reached the age of eighteen. However, if a minor is inclined to use drugs by another minor, such actions are qualified under Part 1 of Art. 315 of the Criminal Code of Ukraine.

The subjective side of a criminal offense is characterized by direct intent. The very fact of inciting a juvenile to use narcotic drugs and psychotropic substances is a qualifying feature of a criminal offense under Art. 315 of the Criminal Code of Ukraine. Moreover, the inclination of a minor to consume narcotic drugs, psychotropic substances, or their analogs of additional qualifications under Art. 304 of the Criminal Code of Ukraine does not need it. If a minor is inclined to use narcotic drugs, psychotropic substances, and their analogs and the use of other intoxicants, such crimes must be classified as a set of crimes under Part 2 of Art. 315 and Art. 324 of the Criminal Code of Ukraine.

During the study of this topic, the level of criminal prosecution for criminal offenses under Art. 315 of the Criminal Code of Ukraine from 2013 to 2019. For 6 years in Ukraine 1931 convictions under Art. 315 of the Criminal Code of Ukraine "Predisposition to the use of narcotic drugs, psychotropic substances and their analogs and precursors." Over the past 6 years, the number of indictments has decreased under Art. 315 of the Criminal Code of Ukraine, in 2013489 convictions were passed, in 2014408 sentences were passed, in 2015 - 297 sentences, in 2016 191 sentences, in 2017 - 207 convictions, in 2018201 sentences were passed, and in 2019132 convictions were handed down in 2006.

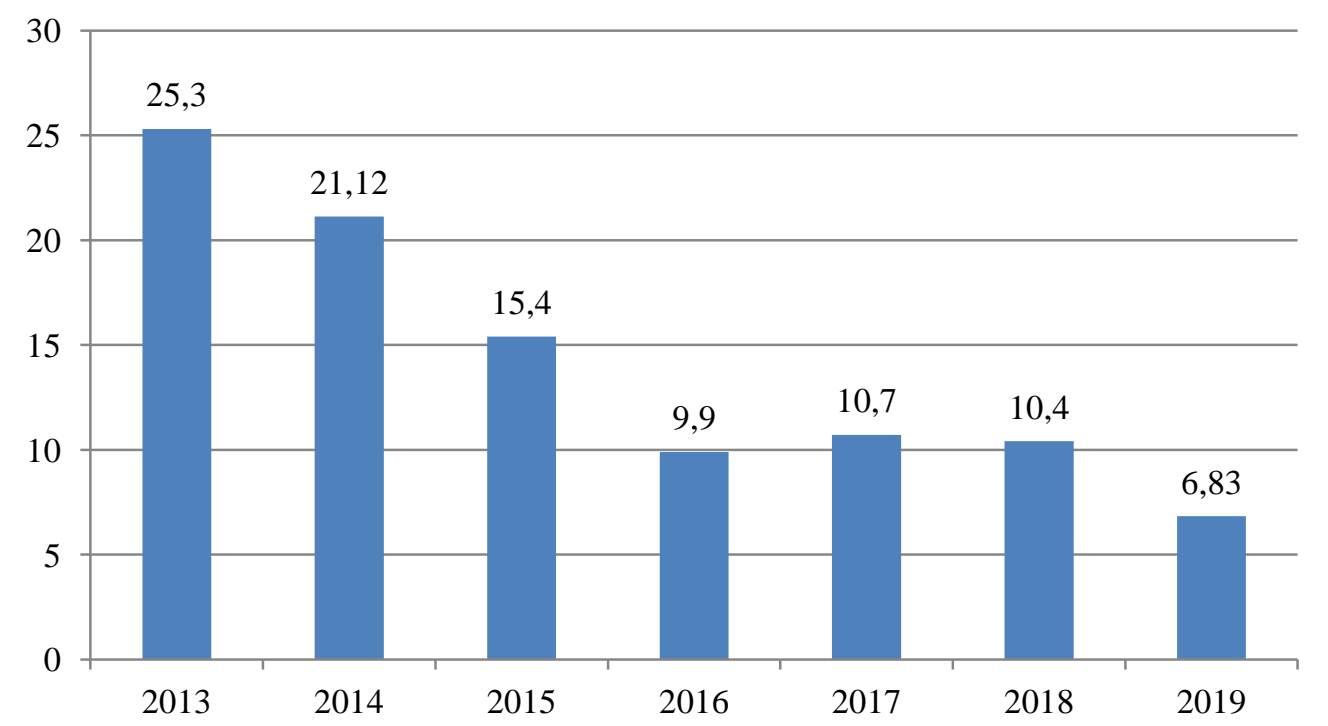

Fig. 3. Dymamics of convictions for years from 2013 to 2020 under art. 315 "Predisposition to the use of narcotics substances or their anologues", \% 
On a territorial basis, the largest number of sentences was handed down in Zaporizhia oblast (253), Dnipropetrovsk oblast (217), Donetsk oblast (122), Vinnytsia oblast (121), Kharkiv oblast (116), Sumy oblast (104), and Mykolaiv oblast (103) oblasts (Annex 14).

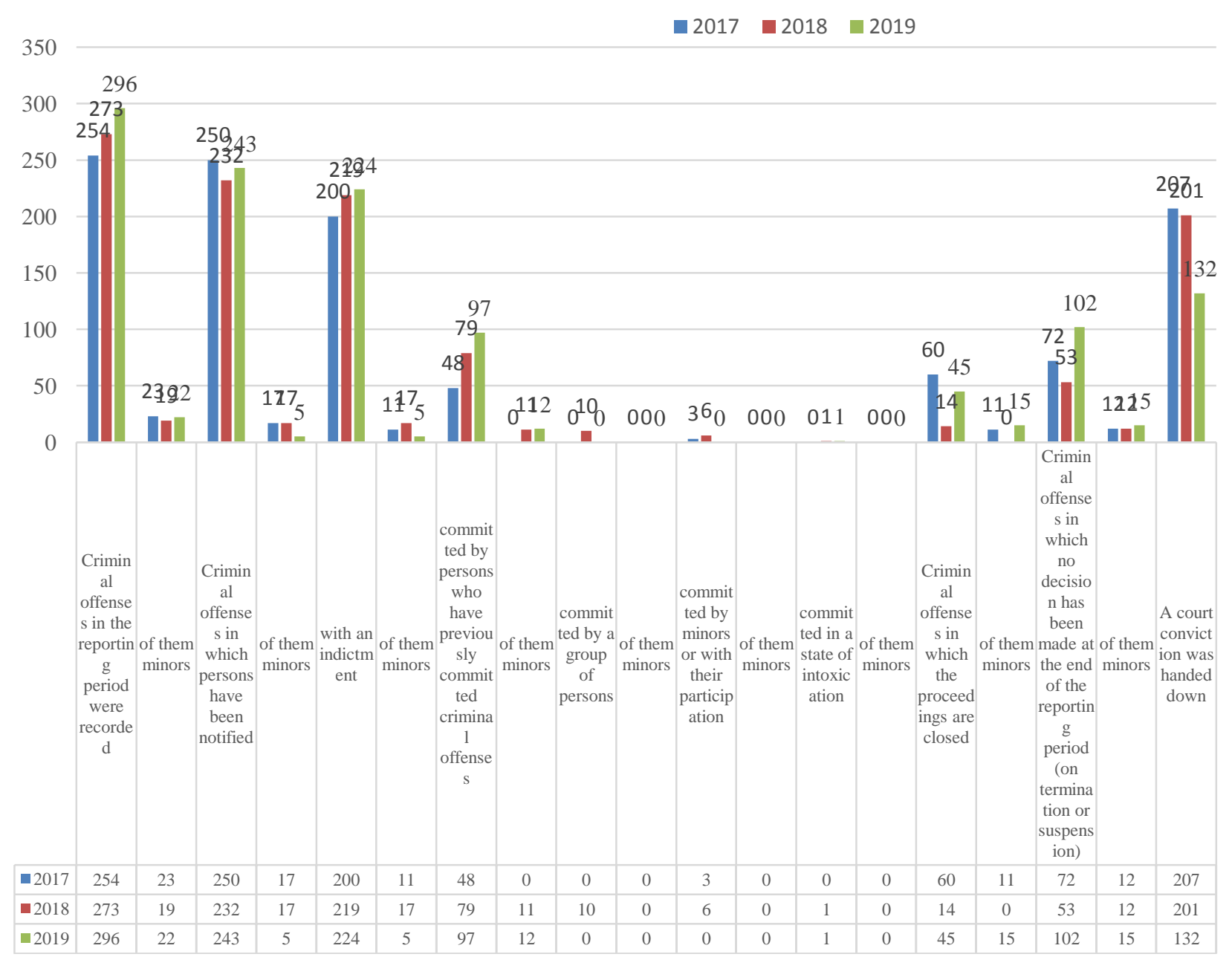

Fig. 4. Dynamics of committing criminal offenses under Art. 315 of the Criminal Code of Ukraine

Thus in 2017254 criminal proceedings on signs of the criminal offense provided by Art. 315 of the Criminal Code of Ukraine, of which 11 were committed by minors, 48 criminal offenses were committed by persons who had previously committed criminal offenses, and convictions were handed down in 207 proceedings. In 2018, 273 criminal offenses under Art. 315 of the Criminal Code of Ukraine, of which 17 were committed by minors, 48 persons who had previously committed criminal offenses, and 201 criminal proceedings were convicted. During 2019, 296 criminal offenses were registered, of which 5 were committed by minors, 97 were committed by persons who had previously committed criminal offenses and 132 convictions were passed [8]. 
According to the results of the study, it is seen that the dynamics of committing criminal offenses under Art. 315 of the Criminal Code of Ukraine is gradually decreasing.

Conclusions. In conclusion, it can be noted that juveniles who are subjected to violence, primarily mental, do not have strong social ties, stable views, are deprived of parental love, care, and have increased victimization in the above criminal offenses. In addition to victimhood, such adolescents acquire criminal potential because such children do not have a model of normal, healthy behavior.

Based on such methods of mental violence against a child as humiliation, contempt, and terrorism, it should be noted that at a time when parents threaten or intimidate to subdue her will, the psyche of a minor is crippled. Growing up, the latter try to realize themselves and in any way prove that they are worthy of respect, and in some cases, on the contrary, aim for revenge, and the victims of such subjects are usually individuals or habits that embody the image of a child abuser.

\section{References:}

1. Lishchynska, A.O. (2008) Profilaktyka psykholohichnoho nasylstva u simi ta osvitnomu seredovyshchi: metodychni rekomendatsii [Prevention of psychological violence in the family and educational environment: guidelines]. Kiev: Milenium [in Ukrainian].

2. Tuzov, A. (2008) Hlybynni determinanty maniakalnykh zlochyniv [Deep determinants of manic crimes]. Pravo Ukrainy, 1, 96 - 102 [in Ukrainian].

3. Sviechnykova A.S., (2008-2009) Fenomen nasyllia nad ditmy v rodyni [The phenomenon of violence against children in the family] Visnyk VolHU, seriia 9, 7, 14-17 [in Ukrainian].

4. Kolinko O.O., (2013) Viktymolohichna kharakterystyka dovedennia do samohubstva [Victimological characteristics of leading to suicide] Doctor's thesis. Kiev [in Ukrainian].

5. Maihur, O.S. (2013) Psykholohichni ta pedahohichni problemy roboty z delinkventamy [Psychological and pedagogical problems of working with delinquents]. Yurydychna psykholohiia ta pedahohika - Legal psychology and pedagogy,1, 227-233 [in Ukrainian].

6. Pro zareiestrovani kryminalni pravoporushennia ta rezultaty yikh dosudovoho rozsliduvannia za 2017 rik [About registered criminal offenses and the results of their pre-trial investigation for 2017] https://old.gp.gov.ua Retrieved from https://old.gp.gov.ua/ua/stst2011.html?dir_id=113897\&libid=100820\&c=edit\&_c=fo\#[in Ukrainian].

7. Pro zareiestrovani kryminalni pravoporushennia ta rezultaty yikh dosudovoho rozsliduvannia za 2019 rik [About registered criminal offenses and the results of their pre-trial investigation for 2019] https://old.gp.gov.ua Retrieved from https://old.gp.gov.ua/ua/stst2011.html?dir_id=113897\&libid=100820\&c=edit\&_c=fo\#

8. Pro zareiestrovani kryminalni pravoporushennia ta rezultaty yikh dosudovoho rozsliduvannia z 2017 po 2019 rik [About registered criminal offenses and the results of their pre-trial investigation for 2017 to 2019] https://old.gp.gov.ua $\quad$ Retrieved

https://old.gp.gov.ua/ua/stst2011.html?dir_id=113897\&libid=100820\&c=edit\&_c=fo\#

9. Summary data of the results of the survey of minors on cases of mental (domestic) violence against them, bullying (at school, among teachers, etc.) (in\%, 1570 people)

Received: August 07, 2020 Approved: September 28, 2020 